\title{
Commercial Banks and Minority Entrepreneurship
}

\section{Introduction}

Hardships imposed by race and poverty have severely limited ownership of productive resources by members of minority groups. ${ }^{1}$ Minorities control less than $3 \%$ of businesses in the United States, although they constitute $15 \%$ of the population; and they own only $25 \%$ of businesses located in ghettoes, although they comprise a substantial proportion of the ghetto population. ${ }^{2}$ Receipts of minority-owned businesses amount to less than $1 \%$ of total U.S. business receipts. ${ }^{3}$ This stark imbalance in ownership has spawned a broad range of programs aimed at promoting "minority economic development." Three main approaches have been taken. First, major corporations have established subsidiaries ("spin-offs") in urban ghettoes, with ownership immediately or eventually devolving to minority entrepreneurs or community groups. ${ }^{4}$ A second approach has been to build Community Development Corporations (CDC's) in the ghettoes. The CDC is a community based corporation which sells shares in its own businesses to community residents or finances businesses controlled by individuals in the community. ${ }^{5}$ The third approach has been to form free-standing businesses owned by minority entrepreneurs. Such enterprises have no special relationship to parent corporations or to ghetto community organiza. tions.

Commercial banks have proved to be the major private sector institu-

- Research for this piece was made possible by financial support from the Ford Foundation. Special thanks for critical help are owed to Ford Foundation Vice-President Mitchell Sviridoff, and to Program Officer Eamon Kelly. The views expressed herc, however, are not assignable to either of them or to the Ford Foundation.

1. Throughout this study, the term "minority" is used to refer to non-white racial minorities.

2. S. Levitan, G. Mangum \& R. Tagcart III, Economic Opportunity in tile GHetto: The Partnership of Government and Business 5 (1970); A. Jennings, S. Synnott \& E. Graham, A Note on Black Capitalism 9-10 (Harvard Business School Note EA-R555, 1969); H. Samuels, Compensatory Capitalism in BLACK ECONOMIC DEvELOPNENT 60, 62.63 (W. Haddad \& G. Pugh ed. 1969).

3. A. Jennings, S. Synnott \& E. Graham, note 1 supra, at 9-10.

4. Examples are plants started by IBM in Bedford-Stuyvesant, New York City, by AVCO in Roxbury, Boston, by Fairchild-Hiller in Baltimore, and by Acro.Jet General in Watts, Los Angeles.

5. Some CDC's have been financed under Title I-D of the Economic Opportunity Act of 1964, 42 U.S.C. $\$ \$ 2763-68$ (Supp. V, 1970), for example, the Bedford-Stuyvesant Restoration Corporation (New York), The Hough Development Corporation (Clcveland), and the North Lawndale Economic Development Corporation (Chicago). 
tion aiding the establishment of such free-standing minority-owned businesses. ${ }^{6}$ These banks have also financed changes in ownership from white to minority businessmen and have supported expansion of existing minority-owned businesses. The purpose of this Note is to explore the extent and complexion of the special efforts of commercial banks to finance free-standing minority-owned small businesses.?

The Note does not attempt to analyze fully the concept of minority economic development; nor, correlatively, will it attempt to evaluate the creation of free-standing businesses as one of several strategies for achieving economic development of the ghetto or economic equality of the races. The focus will be simply on the nature and, where possible, the effectiveness of the relationship between commercial banks, acting primarily as lenders, and individual minority entrepreneurs. Because special programs aimed at individual entrepreneurs are not limited to the development of businesses within the ghetto or barriobusinesses which characteristically face markets with low-income buyers and high cost-free-standing businesses probably stand a greater chance of surviving. However, to the extent that new free-standing businesses are located outside the ghetto and are controlled wholly by individual entrepreneurs, they do not offer the collateral economic, political and social benefits to an impoverished minority community which broader community economic development could provide.

\section{A. The Process of Creating Businesses: Problems Facing Minority Entrepreneurs}

Prospective minority entrepreneurs face problems at four major stages in the process of creating free-standing businesses. During the first stage-loosely called "packaging"- the borrower prepares to deal with the credit market. He must undertake elementary feasibility studies, draw up cash-flow and balance sheet projections, and prepare the other documents normally required for a business loan. ${ }^{8}$

6. Of course commercial banks do not exhaust the range of financial institutions. But Small Business Investment Companies' involvement, to the extent there is any, is with equity financing. See note 47 infra. Insurance companies' efforts hare been devoted mainly to financing low-income housing. And investment banks have thus far undertaken no major efforts toward aiding minority economic development.

7. The Small Business Administration (SBA) definition is taken when minority-owned businesses are referred to as "small businesses." This actually encompasses a broad range, from owner-no employee "Mom and Pop" stores to manufacturing concerns with 250 employees or, in some cases, more. Warehousing operations are "small" if annual receipts do not exceed \$1 million. 13 C.F.R. \& 121.3.10 (1970). When the text compares amaller or larger minority-owned businesses, the comparison takes place within the ample range of enterprises denominated "small" by the SBA.

8. Although packaging services are scarce, several organizations have been created to 
Second, the prospective businessman must procure "equity financing." The term "equity financing," in its strictest sense, refers to business financing based on the sale of an ownership interest. As used by those involved in financing minority-owned businesses, however, the term encompasses the sale of long-term subordinated debt obligations as well. ${ }^{9}$ The ingredient common to both forms of equity financing, from the point of view of the entrepreneur, is the freedom from repayment obligations during early years of the business's operation.

The borrower then faces the third problem, that of acquiring debt financing. Efforts at this stage depend in part on success at the second, since the amount of money which small businessmen are able to borrow from banks depends on the size of the equity base in the business; traditionally, small businessmen have been able to borrow amounts no

perform these services. Typically funded by the federal government, corporations and foundations, examples of packaging institutions are the Rochester Business Opportunitics Corporation, the Chicago Economic Development Corporation, Capital Formation (New York City), and the Coalition Venture Corporation (New York City).

This Note is concerned with commercial banks and their ability to finance high-risk minority entrepreneurs. Packaging agencies contribute to such bank efforts in two ways: to the extent which packaging and post-loan assistance are available and enlance the likelihood of a minority business' success, these services should reduce delinquencies and failures for the banks; second, packagers save banks money by performing much laborious pre-loan review.

There are at least two conceptual problems, however, with packaging agencies, One is that packagers insulate banks from an important phase in the processing of a high.risk minority loan, and thereby forestall institutionalization of minority lending. The second problem is that packagers create an incentive for banks to refer all "unbankable" minority loan applicants outside for initial screening, and by so doing introduce atn artificial quasi-monopolistic structure into minority loan applicants' access to credit markets. The existence of one high quality but understaffed packager in a city, and rarely arc there more, creates a potentially troublesome bottleneck through which minority bor. rowers must slowly pass if they are to receive credit.

The first problem, at least currently, is moot. Most banks are in no position to under. take the functions performed by packagers. Even banks which have special programs and which do a substantial amount of dealing directly with borrowers find in some cases that packagers have a comparative advantage in dealing with borrowers in the most rudimentary stages.

The second objection is more serious. It may already be in some cities that access to credit is restricted monopolistically by the scarcity of packagers and banks' reliance upon them. To the extent that banks' own programs are capable of dealing with borrowers from the start, this bottleneck is eased. That the banks interviewed had an average of only" $34.5 \%$ of their loans made in conjunction with such "auxiliary institutions" (See Table 2 infra) may suggest that the banks most actively devoted to developing minority businesses possess some sort of "packaging" capability.

But because existing packagers invariably have substantial backlogs of applications, it is fair to assume that such bottlenecks do exist. Interviews with the following: Roland Burris, Continental Illinois National Bank, in Chicago, July 9, 1970; David L. Keller, American National Bank and Trust Company of Chicago, in Chicago, July 10, 1970; Garland C. Guice, Chicago Economic Development Corporation, in Chicago, July 18, 1970 [hereinafter cited as Guice, CEDC Interview]; William Zucker, Job Loan Corporation, in Philadelphia, July 6, 1970 [hereinafter cited as Zucker, JLC Interview]; Ed Luccro, Colorado Economic Development Association, in Denver, July 22, 1970 [hercinafter cited as Lucero, CEDA Interview].

9. Interview with Miss A.V. Krieg, Marine Midland Bank, in Rochester, N.Y., June 29, 1970. 
greater than their business's equity, or net worth. Debt financing has performed a number of important functions for businesses, from financing construction (long term mortgages) to financing seasonal inventory needs or accounts receivable (very short term loans). In the minority enterprise context, however, the lack of available equity within the borrower's personal reach and the lack of outside equity sources have driven borrowers and debt financers to rely almost exclusively on debt financing for all the financing needs of the business.

The final problem for the prospective minority entrepreneur is obtaining post-loan assistance. ${ }^{10}$ If the businessman has merely borrowed for expansion, he may need no post-loan help, but if he is managing a business for the first time, he may need help in setting up bookkeeping systems, planning inventory levels, or laying out marketing strategies.

A minority-owned business's search for debt financing-the phase of business creation upon which this Note will focus-almost always requires the assistance of commercial banks. As a result, in recent years there have been calls for expanded lending to aid minority entrepreneurs.

\section{B. Evaluating Commercial Bank Performance}

To stimulate debt financing for prospective minority entrepreneurs who could not otherwise have obtained it, both the American Bankers Association (ABA) and the Small Business Administration (SBA) announced long term minority lending goals in 1968. The ABA simply appealed to banks to undertake one billion dollars of "high-risk" lending to minority borrowers by $1975 .{ }^{11}$ The SBA's appeal for more minority enterprises, on the other hand, was formalized in Project OWN, a program launched soon after Howard Samuels was appointed administrator of the SBA in the summer of 1968. An ex-businessman

10. Packaging and post-loan assistance are not necessarily arailable from the same source. In fact, all bankers interviewed agreed that the critical ingredient of post-loan assistance is virtually unavailable.

Most banks require monthly or quarterly statements from borrowers, but rarely are they received from recipients of minority enterprise loans, and even more rarely are they studied. No banker interviewed thought his bank's monitoring procedures were sensitive enough to forewarn of impending trouble. Banks have tended to place responsibility for follow-up on their lending officers, and these officers are usually too busy with new loans to do more than make an occasional telephone call or visit to the new cntrepreneur. Packaging agencies admit that they are also weak on following-up loans. Those agencies are under relatively close periodic scrutiny from their funding sources, and yicld to the imperative of manifesting high performance. The result is a commitment of resources to pre-loan work to the relative exclusion of less visible post-loan assistance. Guicc, CEDC Interview; Zucker, JLC Interview.

11. Interview with Peter F. McNeish, Executive Secretary, Committec on Urban Affairs, American Bankers Association, in Washington, D.C.. June 22, 1970. 
who believed that private development was crucial to solving urban and racial problems, Samuels hoped to use loan guarantees to stimulate a major increase in debt financing of high-risk minority businesses by commercial banks. His twenty year goal was to bring the proportion of businesses owned by minorities into line with the proportion of minorities in the population. ${ }^{12}$ Project OWN aimed at financing 10,000 businesses in the first year, a number increasing to 20,000 businesses per year thereafter, and finally reaching a 40,000 annual rate in the late 1970's. ${ }^{13}$

This Note will attempt to assess how commercial banks have responded to calls for increased lending to minority entrepreneurs. Bank performance could, at least in theory, be measured against the goals announced by Project OWN or the ABA. Performance could also be measured against demand for minority loans on any given set of repayment terms or against some other standard of "need" based, for example, on a "desirable" scale of business or on their "degrees" of "labor intensity." But neither Samuels nor anyone else has really justified the choice of any particular goal for bank lending. Such a justification would necessarily entail a sophisticated analysis of the need for and the various approaches to minority economic development. In addition, there are serious methodological difficulties with using any of the suggested goals. The Project OWN and ABA goals are too crude to be usecl as guides to increased understanding of the debt financing process. The demand standard is so complex as to be impossible to ascertain with present information; it also would be so crude as to hide important aspects of enterprise creation.

Consequently, this Note takes the more modest approach of assuming that some "large," if unspecified, increase in the level of lending is a desirable goal if minority entrepreneurship is to increase. Thus it does not attempt to decide whether a "sufficient" volume of loans is being made or to analyze what constitutes "sufficiency." However, in order to achieve any substantial increase in lending, progress towards certain interrelated sub-goals of minority lending is necessary. To facilitate description of bank performance, therefore, this Note identifies five sub-goals which together can be used to describe or measure the nature

12. S. Levitan \& R. Taggart, III, Developing Business in the Ghetto, in I Economic Development Problens AND Materuas 241, 247 (W. Farr, Jr. ed.), (New York University Law School, 1968) [hereinafter cited as I Farr].

13. New York Times, Aug. 14, 1968, at 16, col. 1; H. Samuels, Development of Minority Business Ownership . . Executive Summary (undated mimeo), at 12. 
and volume of the loan flow. ${ }^{14}$ For there to be an increase in the creation of free-standing minority businesses, this Note assumes that:

1. There should be an increased flow of loans to high-risk minority businessmen. ${ }^{15}$

2. The loans should be directed to those businesses most likely to survive. While it is difficult to measure performance as to this sub-goal directly, certain inferences can be drawn from the characteristic failure rates of types and sizes of businesses receiving loans. ${ }^{16}$

3. Bankers must be willing to forego traditional credit prerequisites, such as equity financing, management experience and collateral. Without such flexibility, banks will by definition fail to increase lending to minority borrowers who could not otherwise have obtained credit.

4. Banks must be willing to mitigate the shortage of equity financing by structuring loan terms to overcome the potentially crippling debt service costs of businesses financed largely by debt. ${ }^{17}$

5. Minority lending must be institutionalized by banks in a way that maximizes outreach to potential borrowers, minimizes stigma,

14. No supply side analysis can accurately describe reality without accounting for demand. Throughout this piece, judgments are made which assume an unsatisfied demand by potential minority entrepreneurs for credit. One can have no a priori grasp of the amount of this unsatisfied demand. Based upon interviews and the accomplishments of certain banks, however, the following assumptions are made:

a. There exists a large potential demand in black communities for busines loans.

b. Much of this demand is not cognizable by credit markets operating in traditional

ways. Several consequences ensue:

(1) the role of packaging and post-Ioan assistance as ways to expand the ability of the potential minority entrepreneur to utilize credit profitably is cnhanced;

(2) to make loans to high-risk minority borrowers, banks must be willing to forego traditional, and arguably rational, credit prerequisites;

(3) banks which do not undertake special efforts of their own and/or do not establish relationships with packagers and other referral sources are unlikely to make lozns to high-risk minority borrowers.

c. Business loans to new high-risk minority borrowers need not be in support of small, marginal businesses, although the ability to losn money to more sizeable and promising ventures requires more planning on the part of the bank.

15. Use of an increased flow of loans as a criterion of performance, as noted above, is somewhat troublesome, since there is no way of knowing when "enough" credit is available. At this stage in the history of the minority entrepreneurship effort, however, there are still queues at the minority lending windows of commercial banks with special programs. Further, at many banks and in many cities, such lending windows do not jet exist. For these reasons, a performance criterion predicated simply on an unspecified increase in the flow of credit largely avoids the risk of insisting on an over-supply of credic.

16. See the findings of the American Bankers Association and Federal Deposit Insurance Corporation studies, discussed in note 40 infra.

17. For a discussion of recent efforts to expand the availability of equity financing for minority entrepreneurs, see note 47 infra. 
and maximizes lending officer incentives to make loans to minority borrowers. ${ }^{18}$

It is important to recognize at the outset that the loans made by a bank in accordance with the sub-goals would be "soft," absent govern. ment subsidy. A loan is "hard" only when the expected present value of the repayment stream, discounted by the yield of loan resources in other uses, is equal to or greater than the amount of the loan. Prime borrowers receive low rates because risk is unusually small and balances maintained on deposit are unusually large, thereby boosting the effective value of payments, allowing lower interest rates along with profitability. Administrative costs are also small relative to the revenue generated.

In the case of minority borrowers, however, the sub-goals describe a performance standard involving high-risk loans made with long maturities and repayment structures tailored to the cash flow needs of a new business financed primarily with debt obligations. Unless interest rates charged are commensurate with the high risk, the expected present value of the repayment stream of a high-risk minority loan will be less than the amount of the loan, and the loan will be "soft," containing, in effect, a grant component. Longer terms of repayment, forgiveness of principal repayment, and larger administrative expenses serve to enlarge that grant component. Because softness also means lesser profitability, it is likely to have marked effects on the flow of loans and the prospects for institutionalization of minority lending at banks.

\section{Methodology}

To evaluate bank performance in terms of these five indices an attempt was made to obtain both national aggregate data where available and detailed data on those banks which have made intensive efforts to expand minority lending. On the assumption that most high-risk

18. It may be asked why institutionalization of high-risk lending at banks is a sub.goal to the broader goal of expanded minority lending. Why should the government itself not undertake minority lending, leaving subsequent financial needs of successful venturcs to the profit-sensitive private sector?

There are two basic arguments in defense of a joint private sector-public sector ap. proach. First, any given budgetary amount is likely to be more cost-effective if used for incentives rather than direct loans. This was the discovery behind Project oWN which underwrote that program's substantial achievements. Even if one were to abstract away from the realpolitik of the budgetary process and hypothesize an unlimited ability of the federal government to raise money and spend it, significant administrative and "tax fric. tion" costs would be incurred in a direct lending approach. Also, there is no reason to assume that lower level civil servants would be any more relaxed about risk-taking than bank lending officers.

The second basic argument is that the "joint venture" approach to minority cntre. 
loans are made under the aegis of SBA programs, ${ }^{10}$ figures have been computed from raw, unpublished SBA data to obtain an approximation of the national picture as to the first two sub-goals of bank performance-the size of the loan flow and (inferentially) the scale and type of businesses receiving credit..20 As to credit prerequisites and loan terms, SBA requirements provide a limit, but the SBA compiles no data. Nor does the SBA catalogue special bank programs promoting minority lending.

The ABA reports that of the three hundred largest commercial banks in the United States, eighty-nine have established special lending programs for minority entrepreneurs. ${ }^{21}$ In terms of special efforts to aid minority businesses, then, banks vary substantially. To assess the performance in terms of the five sub-goals of those banks which have made the greatest efforts, field interviews were conducted in the summer of 1970 at fourteen banks in seven cities. These institutions represent those commercial banks in various geographic regions ${ }^{22}$ which have demonstrated the greatest commitment of time, energy, and loan resources to the financing of high-risk minority enterprises. ${ }^{23}$

preneurship may be producing a significant external benefit in the form of reduced racial discrimination in credit markets. Even if there is presently "too litule" lending being done by banks, all evidence is that banks which have taken minority entrepreneurship seriously are at least giving serious consideration to minority group loan appliants.

19. See pp. 622-24 infra.

20. These statistics are unfortunately incomplete, as the categories included have become progressively more sophisticated and useful from fiscal 1908 to the present. Some temporal comparisons are thus impossible.

21. Urban Affairs Committee, The American Bankers Association, Urban Affirs Survey 9 (undated) [hereinafter cited as ABA Survey].

22. In selecting the cities, an effort was made to include at least one city in the Northeast, the South, the Mid-west, and the Far-West. Choices among cities were made on the basis of expected productivity of interviewing time.

23. The list of cities and banks was derived with the generous assistance of Pcter F. McNeish, Executive Secretary, Committee on Urban Affairs, American Bankers Association, in Washington, D. C., June 22, 1970. The list is not exhaustive-some difficult choices were governed by the constraints of time and stamina. The banks at which interviews were conducted were: Atlanta: Citizens \& Southern National Bank, July 14, 1970; Chicago: American National Bank and Trust Company, July 10, 1970; Continental Illinois National Bank, July 9, 1970; First National Bank of Chicago, July 9, 1970; Hyde Park Bank and Trust Co., July 9, 1970; Denver: Colorado National Bank, July 21, 1970; Denver U.S. National Bank, July 20, 1970; New York City: Chase Manhattan Bank, July 28, 1970 (data includes loans made by that bank's Small Business Investment Company, the Chase Manhattan Capital Corporation); Philadelphia: Central Penn National Bank, July 7, 1970; First Pennsylvania Banking \& Trust Company, July 6, 1970; Girard Bank, July 8, 1970; Rochester: Marine Midland Bank, June 29, 1970; San Francisco: (all data are for banks' state-wide minority lending activities): Bank of America, July 24, 1970; Wells Fargo Bank, July 24, 1970.

Bank data when given in the text will usually be anonymous, as several banis have requested. The sampling technique described above is far from rigorous, but proved to be the most expeditious way of working up a list of "active" banks. Nothing chimed from the data necessitates true representativeness.

Although quantitative questions were sent ahead, much of the numerical data gathered is only approximate. Its accuracy is not uniform among the banks. 
In the sections that follow, this Note will present the SBA and field interview data, suggest implications in terms of the five sub-goals, and propose steps to accelerate bank participation in minority lending.

\section{Aggregate Bank Response}

\section{A. Small Business Administration Programs}

The two SBA programs of greatest interest to prospective minority entrepreneurs and to commercial banks interested in financing those entrepreneurs are the Economic Opportunity Loan (EOL) and the "7(a)" Business Loan. The purpose of both programs is the encouragement of small business development. Under the programs, the SBA can loan money directly, participate with private sector institutions in a joint financing, or guarantee loans made directly by banks. ${ }^{24}$

On both direct loans and the SBA share of participation loans under EOL, the interest rate is $55 / 8 \%$ per year. On participation loans, the private sector participant cannot charge more than $8 \%$ on his share of the joint financing. ${ }^{25}$ On guaranteed loans, the lending institution must set a "legal and reasonable" interest rate. 20

To qualify for an EOL loan, a borrower must have "been denied the opportunity to have access to adequate financing on reasonable terms, through normal lending channels because of economic or social

Because the study is concerned with the extent to which banks are consciously working to expand loans to high-risk minority entrepreneurs, data was gathered from the banks interviewed only with respect to business loans made under the auspices of a special program or efforts, denominated "minority loans" in this study. The data reported herc thus do not represent all the business which banks do with minority borrowers because they do not include loans made in the ordinary course of business.

In addition, minority-owned banks were excluded from the sample because it would have been difficult to get accurate information on "special efforts" from banks which deal mostly with minority borrowers and because the concern of this study is the extent to which the commercial banking industry has expanded and institutionalized minority lending programs. Black-owned banks in the U.S., for example, are only twenty in number with total assets of \$162 million, compared with $\$ 334$ billion in total assets for all banks in the country. T. Cross, BlaGk Capitalisa 50 (1969).

24. 42 U.S.C. \& 2902 (Supp. V, 1970) and 15 U.S.C. \& 636 (Supp. V, 1970), respectivcly。 The SBA administers other programs as well, including Disaster Loans, Displaced Business Loans, Local Development Company Loans, and the Small Business Investment Company program, including Minority Enterprise Small Business Investment Companies (MESBIC), discussed in note 47 infra. Apart from the EOL, 7(a), and MESBIC programs, the only other SBA program involved in financing enterprises for minority group entrepreneurs is the Local Development Company Loan. This device is mainly used by development companies to make improvements on real estate for subsequent business use, and is thus outside the focus of this study, which is bank financing of the businesses themselves.

25. 13 C.F.R. $\S \S 119.31$ (c)(1), (2) (1970).

26. Id. at (c)(3). 
disadvantage."27 The EOL program authorizes loans of up to $\$ 25,000$ for up to 15 years, ${ }^{28}$ and loans may be guaranteed up to $100 \% 0^{20}$

The 7(a) loan program, alternatively called the "regular business" loan, has no requirement that the borrower be from an economically disadvantaged group. Important differences between the 7(a) and EOL programs are that the SBA's guaranteed share of a 7(a) loan can be as much as $\$ 350,000$, but that the guarantee can equal no more than $90 \%$ of the loan. ${ }^{30}$

The base line from which to measure the aggregate bank response to the call for increased loans to high-risk minority enterprises is fiscal 1968, since Project OWN and the ABA announced their goals early in fiscal 1969.

Three major changes were implemented under Project OTVN. First, administrative procedures were streamlined, so that SBA approval or disapproval of a loan application could be rendered within 10 days. ${ }^{31}$ A blanket guarantee procedure was developed, whereby a bank could sign an agreement after which a short form could be used for individual loans. 32

Second, credit criteria were changed. Loans to effect a change in ownership of a business, normally prohibited, were allowed for minority borrowers. The proportion of equity financing required in a borrowing was lowered from $50 \%$ of the total financing to $15 \%$, and was made waivable by the local SBA offices if projections indicated a reasonable chance of repayment. Inadequate collateral was to be disregarded if it appeared that a loan could be repaid from future earnings. Principal

27. 13 C.F.R. \& 119.21(b) (1970). Another requirement is that the funds should be otherwise unavailable. 13 C.F.R. \$ 119.21(f) (1970). Yet there is no mention of how this is to be proved, save that, "the applicant's bank of account, if any, will be contacted to determine its willingness to finance the applicant independently, to participate with SBA, or to make a loan with a guaranty by SBA." Id.

28. 42 U.S.C. § 2902 (Supp. V, 1970).

29. 13 C.F.R. \& 119.41(a) (1970).

30. 15 U.S.C. $\$ 636(a)(4)$ (Supp. V, 1970), 13 C.F.R. $\$ \S 119.41(a), 120.2(b)(2)$ (1970). An. other difference between the $7(a)$ and EOL loans is that the requirement of proof that funds are otherwise unavailable is laid out in greater detail for the 7(a) loan. Credit is deemed to be available absent proof of a refusal from a bank (or two banks, in cities over 200,000 in population). This proof must recite the details of the loan and ure reasons for refusal. 13 C.F.R. \& 120.2(a)(1) (1970). The borrower must also show that financial assistance is unobtainable on reasonable terms through a public offering or private placement of stock, through the sale at a fair price of assets unessential to the business' operation, from personal borrowing by the entrepreneur, his partners or sharcholders (without causing them undue hardship), or from other sources of gorernment financing. 13 C.F.R. $\$ 1202(\mathrm{a})(2)(1970)$, cf. note 27 supra.

31. Testimony of Howard J. Samuels, SBA Administrator, Financial Institutions and the Urban Crisis, Hearings Before the Subcomm. on Financial Institutions of the Senate Comm. on Banking and Currency, 90th Cong., 2d Sess. (1968).

32. Id. 
payments on EOL loans could be deferred for 13 months from the date of the note, and smaller payments could be structured for the early years of the loan. ${ }^{33}$

Third, the SBA field staff were instructed to spend more time working with minority borrowers in the preparation of their business and financial plans and loan applications. ${ }^{34}$

\section{B. Flow Of Loans and Types of Businesses Borrowing-The Aggrc- gate Profile}

Before presenting the SBA data, a last caveat is in order-not all high-risk minority loans go through the SBA. ${ }^{35}$ Although there is obviously a strong incentive for a bank to seek an SBA guarantee on such a loan, in some cases there are possible counterbalancing factors. One is an ideological position in some banks that the private sector has an obligation to make minority loans, and should have nothing to do with the government. Another is the quality of the local SBA office and of the bank's relationship with that office-not all SBA offices have liberalized equally under Project OWN and its successor, Project Mainstream. A third is that the SBA insists on loans with fixed amortization schedules (term loans), whereas a business may require the greater flexibility of a line of credit to meet its needs.

On the other hand, the SBA data may be more accurate than banks' claimed totals of minority loans, since those claims may be inflated by the inclusion of loans which are not genuinely "high-risk," a practice called "creaming." Such loans might be unable to satisfy the SBA requirement of proof that the money is not otherwise available. ${ }^{30}$

The SBA data for fiscal years 1968 through 1970 are reproduced in Table 1.

Findings. From this data it is clear that projects OWN and Mainstream accomplished a major increase in the flow of loans to high-risk minority borrowers. The 1,724 minority loans in the EOL and 7 (a) programs combined, totalling $\$ 26.8$ million in 1968 , increased to 6,134 loans totalling $\$ 145.1$ million in 1970 . Minority businessmen obtained $24.14 \%$ of the money loaned by and with the SBA in fiscal 1970 as compared with $5.09 \%$ in fiscal 1968 . Yet the average size of the minority loans made through the SBA increased only modestly, and more than

33. SBA Report on Project OWN, Jan. 1969, in I Farr 130, 134-36; 13 G.F.R. $\$ \$ 119.21$ (c), 119.31(d), 119.31(b) (1970).

34. I Farr 130, 134-36.

35. For a discussion of the extent to which the banks included in the field survey used SBA guarantees, see pp. 631-32 infra.

86. See notes 27 and 30 supra. 
$70 \%$ of minority loans in 1969 and 1970 were EOL loans (maximum $\$ 25,000)$.

Projects OWN and Mainstream have thus succeeded in involving private sector institutions in minority lending. The amount of private

TABLE 137

SBA DATA

\begin{tabular}{|c|c|c|c|}
\hline & Fiscal 1968 & Fiscal 1969 & Fiscal 1970 \\
\hline \multicolumn{4}{|c|}{ MINORITY, 7(a), EOL } \\
\hline 1. $\frac{x}{4 \pi}$ Loans & 1,724 & 4,016 & 0,134 \\
\hline 2. \$Loans & $\$ 26.8$ mill. & $\$ 85.8$ mill. & $\$ 145.1$ mill. \\
\hline 3. Average size & $\$ 15,545$ & $\$ 21,206$ & $\$ 23,650$ \\
\hline 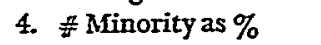 & & & \\
\hline Total 7(a), EOL & $13.94 \%$ & $29.48 \%$ & $43.02 \%$ \\
\hline 5. \$Minority as $\%$ & & & \\
\hline $\begin{array}{l}\text { Total 7(a), EOL } \\
\text { 6. Proportion Which }\end{array}$ & $5.09 \%$ & $14.42 \%$ & $24.14 \%$ \\
\hline $\operatorname{EOL}\left(\frac{\pi}{27}\right)$ & NA & $72.20 \%$ & $73.44 \%$ \\
\hline 7. Proportion Which & & & \\
\hline $7(a)\left(\frac{7}{27}\right)$ & NA & $27.80 \%$ & $26.56 \%$ \\
\hline 8. $\$$ Private & & & \\
\hline $\begin{array}{l}\text { Sector-Related } \\
\text { 9. Private Sector }\end{array}$ & NA & $\begin{array}{l}\$ 53.8 \text { mill.- } \\
\$ 61.6 \text { mill. }\end{array}$ & $\$ 94.8$ mill. \\
\hline Risk Exposure & NA & NA & $\$ 15.7$ mill. \\
\hline $\begin{array}{l}\text { 10. \$ Private } \\
\text { Sector-Related, } \\
\text { Guarantee Progs. }\end{array}$ & NA & NA & $\$ 88.5$ mill. \\
\hline $\begin{array}{l}\text { 11. Private Sector } \\
\text { Risk Exposure, }\end{array}$ & & & 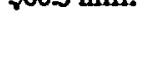 \\
\hline $\begin{array}{l}\text { Guarantee Progs. } \\
\text { 12. \% Private Sector- } \\
\text { Related Which EOL }\end{array}$ & NA & NA & $\$ 9.4$ mill. \\
\hline 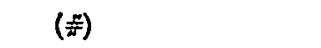 & NA & NA & $49.1 \%$ \\
\hline $\begin{array}{l}\text { 13. \% Private Sector- } \\
\text { Related Which }\end{array}$ & & & \\
\hline EOL (\$) & NA & NA & $22.5 \%$ \\
\hline
\end{tabular}

37. 1968 SBA Management Report; 1969 SBA Management Report pt. 1; 1970 SBA Management Report. Most categories of information reported here vere not reported per se by the SBA, but were calculated from data reported. "Private Sector-Rclated" is the private sector amount lent in participation loans plus the full amount of guaranteed loans. Private sector risk exposure is here defined as the amount of private investment in participation loans plus guaranteed loans net of the share guaranteed by the SBA. Minority lending data from the SBA are available in varying detail for the three fiseal years under study. These data are presented and analyzed in Table 1 . Where data categories are not denominated "minority," the data refer to total SBA lending, and provide information about minority lending patterns only inferentially.

A problem with the SBA data is that the SBA ficld offices may not be strictly enforcing the requirement of proof that the money is not otherwise available, see notes 27 and 30 supra. To the extent this is true, SBA figures may reflect "creaming," or the inclusion of loans not genuinely "unbankable."

The federal government fiscal year is July 1 to June 30; years when referred to throughout this discussion of SBA performance will be federal fiscal years. 
TABLE 1 (Continued)

\begin{tabular}{|c|c|c|c|}
\hline & Fiscal 1968 & Fiscal 1969 & Fiscal 1970 \\
\hline \multicolumn{4}{|c|}{ TOTAL $7(a)$, EOL } \\
\hline 1. Total $\#$ Loans & 12,367 & 13,723 & 14,258 \\
\hline 2. Total $\$$ Loans & $\$ 526.8 \mathrm{mill}$. & $\$ 595.0$ mill. & $\$ 601.0 \mathrm{mill}$. \\
\hline 3. Total $\frac{\|}{\pi} 7(\mathrm{a})$ & 9,476 & 9,494 & 8,719 \\
\hline 4. Total $\$ 7(a)$ & $\$ 495.6$ mill. & $\$ 543.7$ mill. & $\$ 528.3$ mill. \\
\hline 5. Total \# EOL & 2,891 & 4,229 & 5,589 \\
\hline 6. Total \$ EOL & $\$ 31.2$ mill. & $\$ 51.3$ mill. & $\$ 72.7$ mill. \\
\hline 7. Average size & $\$ 42,597$ & $\$ 43,357$ & $\$ 42,151$ \\
\hline 8. Average size, 7(a) & $\$ 52,300$ & $\$ 57,267$ & $\$ 60,590$ \\
\hline 9. Average size, EOL & $\$ 10,792$ & $\$ 12,139$ & $\$ 18,125$ \\
\hline 10. \% Which Gtee (\#) & $32.47 \%$ & $56.89 \%$ & $57.89 \%$ \\
\hline \multicolumn{4}{|l|}{ 11. \% 7(a) Which } \\
\hline Gtee (\#) & $38.79 \%$ & $65.36 \%$ & $75.08 \%$ \\
\hline \multicolumn{4}{|l|}{ 12. $\%$ EOL Which } \\
\hline Gtee (\#) & $11.76 \%$ & $37.88 \%$ & $80.81 \%$ \\
\hline 13. \% Which EOL (\#) & $23.38 \%$ & $30.82 \%$ & $38.85 \%$ \\
\hline 14. \% Which EOL (\$) & $5.92 \%$ & $8.62 \%$ & $12.10 \%$ \\
\hline 15. Rate of Increase ( $\left(z^{n}\right)$ & $10.96 \%$ & & \\
\hline \multicolumn{4}{|l|}{ 16. Rate of Increase, } \\
\hline $7(a)($ t) & $0.19 \%$ & & \\
\hline \multicolumn{4}{|l|}{ 17. Rate of Increase, } \\
\hline EOL (\#) & $46.28 \%$ & & \\
\hline \multicolumn{4}{|l|}{ 18. Rate of Increase, } \\
\hline & \\
\hline $\begin{array}{l}\text { 19. Rate of Increase, } \\
\text { EOL (\$) }\end{array}$ & $64.4 \%$ & & \\
\hline \multicolumn{4}{|l|}{$\begin{array}{l}\text { 20. \% Private Sector- } \\
\text { Related Which }\end{array}$} \\
\hline EOL (\#) & $5.89 \%$ & $16.51 \%$ & $17.47 \%$ \\
\hline \multicolumn{4}{|l|}{$\begin{array}{l}\text { 21. \% Private Sector- } \\
\text { Related Which }\end{array}$} \\
\hline EOL (\$) & $1.59 \%$ & $5.04 \%$ & $5.25 \%$ \\
\hline \multicolumn{4}{|l|}{ 22. Private Sector } \\
\hline Risk Exposure & $\$ 111.7$ mill. & $\$ 121.9$ mill. & $\$ 106.2$ mill. \\
\hline \multicolumn{4}{|l|}{ 23. Rate of Increase, } \\
\hline $\begin{array}{l}\text { Private Sector } \\
\text { Risk Exposure }\end{array}$ & $9.13 \%$ & & \\
\hline
\end{tabular}

sector loan resources which went to minority borrowers rose from something less than $\$ 26.8$ million in 1968 to $\$ 94.8$ million in $1970 . .^{88}$ of this amount, $\$ 88.5$ million $(93.4 \%$ ) in 1970 was in the form of guaranteed loans.

38. 1968 data do not report the amount of money loaned to minority borrotvers by private sector sources. It is obvious, however, that this amount is somewhat less than $\$ 26.8$ million, which is the total amount of money loaned to minority borrowers directly and by private sector sources under SBA programs in 1968. 
The amount which private sector sources had at risk-that is, the amount of private sector participation loans plus the unguaranteed portion of partially guaranteed loans-was unavailable except for 1970 . On the average, private sector lenders in 1970 exposed themselves to a risk of loss on only $10.6 \%$ of the money loaned to minority borrowers under the EOL and 7(a) guarantee programs.

In general, the most dramatic changes in the SBA lending profile were achieved in 1969. All of the minority indices available tapered off considerably in 1970. The amount of money and the number of loans increased by a relatively constant amount, and thus the rate of growth declined significantly in 1970 . The modest gain in average size of minority loans was achieved largely in 1969.

Implications. Although Project OWN never reached its stated goals of 10,000 new businesses in 1969 and 20,000 in 1970, it clearly accomplished a great deal in terms of greater loan flow to minority entrepreneurs and greater bank involvement in minority lending. It seems clear that the device of the government loan guarantee was an important incentive to private sector lenders. An overwhelming proportion $(93.4 \%$ ) of private sector lending in 1970, for example, was conducted with government guarantees; and only a small part of private sector risk exposure was attributable to minority lending.

Since the size of a loan tends to relate to the type and scale of the business, at least where the loan is for start-up expenses, the small size of the average minority loan suggests that a great many of those loans have gone to small, "Mom and Pop" retail or service enterprises ${ }^{39}$ with their characteristic unprofitability and small employment potential.40

39. Zucker JLC Interview. The inference that a small loan is being used to finance a relatively small business depends on the fact of the loan being used for start-up expenses. The SBA data do not report the use to which the loans are put, hence the inference is tentative. That it is a sensible inference is supported by the general emphasis of Projeet OWN on increasing the number of minority-owned businesses.

40. The best sources of information on failures and delinquencies are two recent surveys by the American Bankers Association and the Federal Deposit Insurance Corporation (FDIC). FDIC, Commercial Banks' Repayment Experience in Mfinority Lending, June 1, 1970 (unpublished mimeo) [hereinafter cited as FDIC Study]; ABA Survey. The FDIC surveyed 8 banks selected according to the same criterion employed here-beause they were believed to be "active" in minority lending. The $A B A$, on the other hand, surveyed the nation's 300 largest banks.

The FDIC study reveals that retail and service businesces are indeed the most risky. They account for $65 \%$ of the dollar volume of total loans made, and for $96 \%$ of the delinquent dollar volume. Services prove to be the most risky businesses, amounting to 29\% of total loan volume and $70 \%$ of total delinquent loan volume. FDIC Study, at 4 . A similar but less dramatic pattern emerges with respect to chargeoffs. FDIC Study, at 5 .

The study further finds that larger loans performed generally better than small loans:

As might be expected, the smaller loans had delinquency and changeoff rates higher

than their share of total loans would indicate. At the other end of the seale, loans of over $\$ 25,000$ principal amount performed better than average, by about the same percentages of delinquencies and chargeoffs as their share of the total would suggest. 
The levelling off of many of Project OWN's accomplishments after the first year has several possible explanations. One is that Administrator Samuels, whose zeal initiated and forcefully pushed banks into Project OWN, served only until January 1969, and that his successor has been less able to promote the program. This analysis is not completely persuasive, however, because the SBA is administered through semi-autonomous regional offices, and by civil servants working under both Administrators.

Another possible explanation is that banks in the early phase of Project OWN may have participated more enthusiastically because of guilt engendered by the riots of 1967. To the extent this analysis is true, it suggests that the rationale under which a bank undertakes minority lending, even when guaranteed, is something other than standard profit maximization.

A third explanation is that fiscal 1970 coincided with a period of economic recession, with rising unemployment and tight credit. In such a time, banks are forced to allocate scarce loan resources more carefully and must be certain to continue to provide banking services to their best customers, thereby making credit generally less available to new ventures and particularly to new ventures from which the banks are unlikely to receive substantial deposits. A corollary to this recession hypothesis, however, is that the demand for money to start new businesses decreases when the economy slows down, since the prospects of success in such times are less promising.

While one cannot be clear as to what extent each of these explanations may be correct, all but the last, which explains the tapering off of Project OWN's accomplishments in terms of diminished demand for credit, indicate that the presence of a risk guarantee, while useful, is not sufficient to make minority business loans fully competitive with other lending opportunities.

FDIC Study, at 6.

The $A B A$ survey, relating repayment information from 94 banks, found that $10.4 \%$ of the total number and $17 \%$ of the dollar volume of minority business loans were delinquent. ABA Survey, at 9 . The FDIC study averaged $12.6 \%$ and $5.7 \%$ respectively. With respect to chargeoffs, in the ABA group gross chargeoffs were $4.1 \%$ of total valuc, while in the FDIC group they were $2.8 \%$ of total volume. The $A B A$ study reveals net chargcaffs of $3.8 \%$ of total volume, and the FDIC survey shows $1.0 \%$. ABA Survey at $9 ;$ FDIC Study, at 7 . It cannot, however, be fairly concluded that FDIC banks "did better" bectuse they had full-time staffs devoted to minority lending, because the $A B A$ study included typically small installment loans, which were not included by the FDIC. As a result of this incomparability, the differing loss and delinquency results of the FDIC and ABA surveys are inconclusive. FDIC study, at 7. See also A. Brimmer and H. Terrell, The Economic Potential of Black Capitalism (paper presented at 82nd Meeting of the Amcrican Economics Association, December 29, 1969). 
Commercial Banks and Minority Entrepreneurship

III. Field Survey of the Most Active Banks

A. Flow of Loans and Type of Businesses Borrowing-Banks Surveyed.

Interviews conducted at the fourteen selected banks yielded quantitative information of varying completeness. The most interesting question as to the scale of bank lending which can be asked of the data from these "active" banks is whether and to what extent banks are lending to minority businesses in proportion to each bank's size. The data are reproduced in Table 2.

TABLE 2\$1

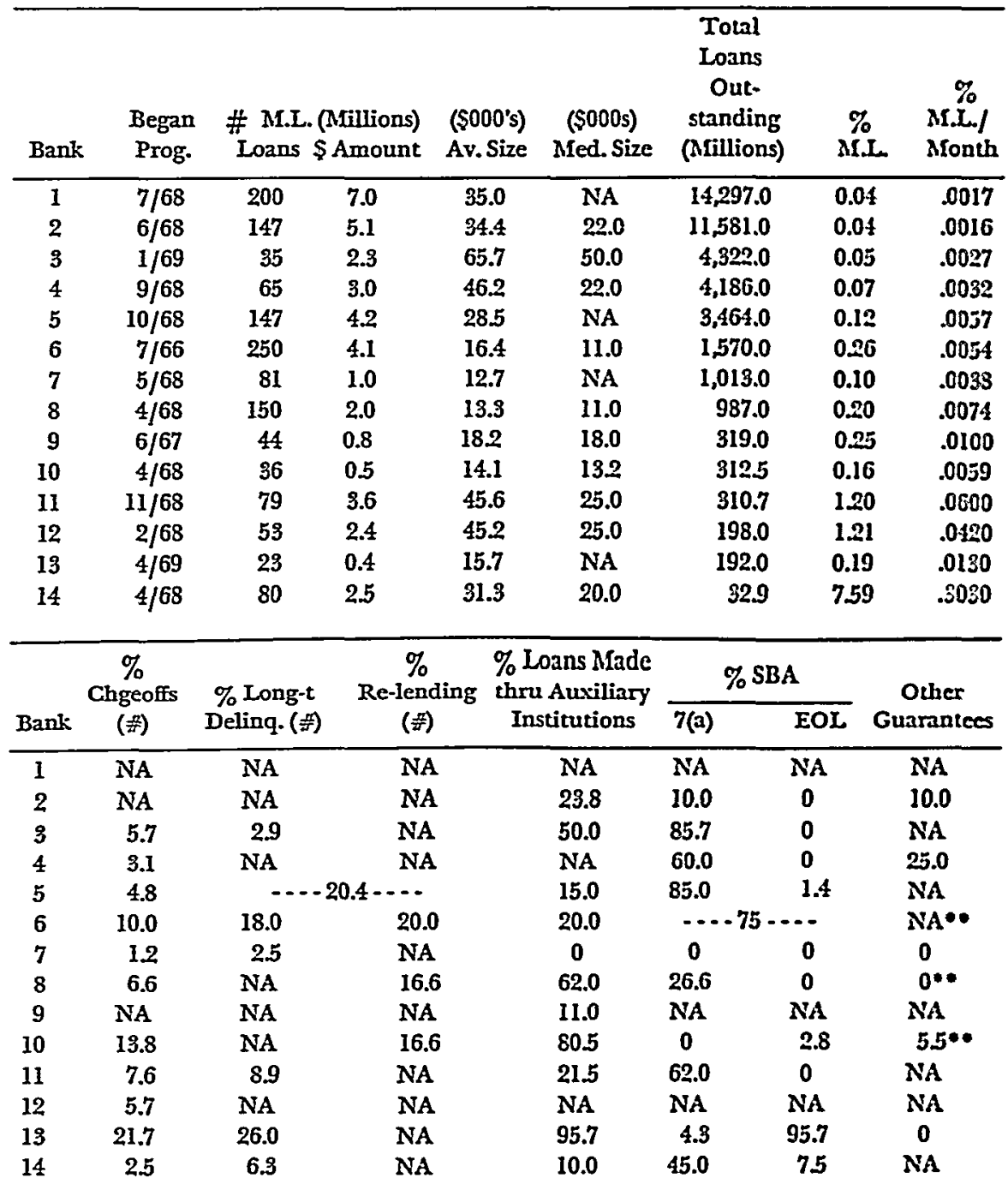

41. Field interviews, note 23 supra. The number of minority (M..L) loans, as noted 
TABLE 2 (Continued)

\begin{tabular}{|c|c|c|c|c|c|c|c|}
\hline Bank & $\begin{array}{l}\% \\
\mathrm{Mfg} .\end{array}$ & $\begin{array}{c}\% \\
\text { Service }\end{array}$ & $\begin{array}{c}\% \\
\text { Retail }\end{array}$ & $\begin{array}{c}\% \\
\text { Wholesaling } \\
\text { \& Other }\end{array}$ & $\begin{array}{c}\% \\
\text { New }\end{array}$ & $\begin{array}{c}\% \text { Existing } \\
\text { But New to } \\
\text { Borrower }\end{array}$ & $\stackrel{\%}{\text { Re-financing }}$ \\
\hline 1 & NA & NA & $\mathrm{NA}$ & NA & NA & NA & $\mathrm{NA}$ \\
\hline 2 & 14.0 & 43.0 & 23.0 & 20.0 & 50.0 & 6.8 & 49.2 \\
\hline 3 & 14.3 & 60.0 & 14.3 & 11.4 & 34.3 & \multicolumn{2}{|c|}{$\ldots 65.7 \ldots$} \\
\hline 4 & 7.7 & 16.9 & 30.8 & 44.6 & 43.1 & 23.1 & 33.8 \\
\hline $\mathbf{5}$ & NA & NA & NA & NA & 50.0 & 20.0 & 80.0 \\
\hline 6 & "few" & \multicolumn{2}{|c|}{$\ldots$} & NA & NA & NA & NA \\
\hline 7 & $1.2 *$ & \multicolumn{2}{|c|}{$\ldots-98.8-\ldots$} & 0 & NA & NA & NA \\
\hline 8 & NA & NA & NA & NA & NA & NA & NA \\
\hline 9 & NA & NA & NA & NA & $\mathbf{N A}$ & NA & NA \\
\hline 10 & 9.5 & 57.1 & 23.8 & 9.5 & 19.4 & 25.0 & 38.8 \\
\hline 11 & 8.9 & 45.6 & 38.0 & 6.3 & 40.5 & 7.6 & 48.1 \\
\hline 12 & 11.4 & 68.5 & 14.3 & 5.7 & NA & NA & NA \\
\hline 13 & $4.3^{*}$ & 75.0 & 20.6 & 0 & NA & NA & $\mathbf{N A}$ \\
\hline 14 & 4.0 & 41.0 & 38.0 & 17.0 & 37.0 & 13.0 & 50.0 \\
\hline
\end{tabular}

1 loan.

- Philadelphia banks also have access to a unique guarantee offered by the Job Loatl Corp., discussed at p. 638 infra.

Findings. The 14 banks sampled had individually made between 23 and 250 minority enterprise loans; in total dollar volume, the loan totals per bank ranged from $\$ 0.4$ million to $\$ 7.0$ million.

above, relates not to the total of loans to minority group borrowers, but only to those made in special programs, i.e. to those which allegedly would not otherwise have been made. "Total Loans Outstanding" is the aggregate loan portfolio of the bank. This figurc was obtained as of June 30,1970 , where possible. Othervise, the most recent figure avall. able was used, which in most cases was total loans outstanding as of December 31, 1969. The resultant error introduced is not substantial, as this number is used only to derive the order of magnitude which minority loans represent in total lending. The "tota1 minority loans" category relates the total loans committed from the beginning of the program to date, hence the "\% M.L." category does not describe the proportion of out. standing minority loans to total outstanding loans. It is instead a rough index relating the dollar value of minority loans to the size of the bank. The \% M.L./month is dlefined in text, p. 631 infra.

The category "\% Loans Made Through Auxiliary Institutions" refers to loans which have been developed by groups and agencies in the various cities. These "packagers" are discussed in note 8 supra.

Although the quantitative questions were sent ahead to intervicwees, many of the numerical data gathered are only approximate. Their quality, candor, and accuracy vary from bank to bank. Another serious problem is the sheer unavailability of comparable data from all of the banks interviewed. This problem consistently arises with respect to losses and the way they are recorded. In some banks, long-delinquent loans are simply maintained on the books, thus artificially suppressing the loss rate. In others, loans whlch are long overdue are "re-cycled"-a new loan is granted to retire the old notes. In still others, losses are more promptly recorded or "charged-off." Because these procedures vary and candor was most elusive with respect to delinquencies and losses, little weight should be given to data in this area. One suspects that the great apparent variability dis. covered in the loss experience of different banks is illusory. For the best available data on delinquency and loss experience, see note 40 supra.

Another weakness is that the data vary in vintage. In some cases the administrative structure of a bank's minority lending program has been operative for two or more years, allowing at least tentative inferences to be drawn from the results. In others, programs are too new for their success to have been reflected in performance data. 
The ratio of total minority loans committed since the beginning of each bank's program to that bank's total loans outstanding (\% M.L.) varied from .04 to 7.59. In general, the larger the bank's total of loans outstanding, the smaller its \% M.L. This strong inverse relationship persists even when the \% M.L./month is calculated by dividing a bank's $\%$ M.L. by the number of months elapsed between the program's commencement and the date of the information to make a rough correction for the duration of each bank's program.

A surprising amount of the increased loan flow from the sampled banks has not been guaranteed. Four banks had SBA guarantees on fewer than $30 \%$ of their loans (by number). Of the seven other banks for which this information was available, four had SBA guarantees on $50 \%-80 \%$ of their loans, and only three had guarantees on $80 \%$ or more.

As to the types of businesses being financed, all banks but one made more than half of their loans to retail and service businesses. No bank made more than $50 \%$ of its loans to new enterprises, and all banks reporting made at least one-third of their loans to businesses where no change in ownership occurred.

Findings as to the delinquency and loss (chargeoff) experience of banks' minority lending programs are unreliable.12

Implications. In analyzing the sub-goal of an increase in the flow of loans to minority businessmen, one is necessarily concerned with the forces which explain and induce such an increase. The negative relationships between bank size and \% M.L., and between bank size and $\%$ M.L./month indicate at least tentatively that banks are involved in minority lending in some relatively fixed amount and are not each making loans in proportion to their sizes. The "fixed" amount is not a rigid one-indeed, there is a considerable range in the number and dollar volumes of minority loans among the institutions surveyed. Most banks do not have particular loan pools limiting their minority lending. What has happened, however, is that larger banks have not committed staff personnel to minority lending in the same proportion as the smaller banks. ${ }^{43}$ The human capabilities of a limited staff have

\footnotetext{
42. See note 41 supra.

43. Interview with Milton Davis, Urban Development Division, Hyde Parik Banking \& Trust Company, in Chicago, July 9, 1970 [hereinafter cited as Davis, Hyde Park Inier. view]; Interview with Joseph C. Angello, Bank of America in San Francicco, July 24, 1970 [hereinafter cited as Angello, B of A Interview]; Interview with Lawrence Toal, Community Economic Development Division, Chase Manhattan Bank, in New York City, July 28, 1970 [hereinafter cited as Toal, Chase Manhattan Interview].

The size of full-time professional staffs devoted to minority lending ranged from one
} 
then operated as an effective ceiling on each bank's minority enterprise involvement. ${ }^{44}$

The surprisingly small proportion of loans made with government guarantees may be attributed to the factors cited above ${ }^{45}$ which operate to deter a bank from pursuing SBA guarantees or, on the other hand, which inflate banks' claimed totals of high-risk loans. Alternatively, banks with expert full-time staffs devoted to minority lending may be able to make profitable loans to some high-risk borrowers without guarantees.

The types of businesses to which loans were made, as reported by the banks, supports the inference drawn from the small size of SBA minority loans-that the increase in minority lending has tended to finance a large number of small retail and service businesses, the classes of businesses most subject to failure. The finding that a substantial portion of minority lending is to on-going enterprises where there is no change in ownership is ambiguous. Formerly uncompetitive units may be borrow. ing to expand and take advantage of economies of scale, or they may be investing in modernized fixtures and equipment, more adequate inventory, or improved marketing procedures. It is also possible, however, that unprofitable businesses which were formerly sustained by intrafamily borrowing are now being carried along by banks.

\section{B. Willingness to Forego Traditional Credit Criteria}

Since high-risk minority borrowers characteristically lack substantial personal or family resources and, to a varying degree, management ex-

to seven. In some cases, a unit performed additional lending functions, e.g. the bank with seven full-time people used these people as its low-income housing loan staff as well. The typical size of staff was between one and three full-time professional cmployecsonly four banks had larger staffs. Although all of those four banks were among the seven largest banks in the sample, the extra personnel commitment is not proportional to size. The second largest bank, for example, has total loans nearly one hundred times greater than the thirteenth largest bank, yet its staff commitment is four times grcater. The smallest bank has a larger staff commitment than the largest bank.

44. It is not implied that this inverse relationship, given the demand for credit and the prevailing level of subsidy, could or should be completely eliminated. Sce note 15 supra. For Bank 1 to bring its \% M.L./month up to parity with bank 14 would entail an increase in its minority enterprise loans of more than $\$ 1$ billion, four times the first year national goal of Project OWN. Since there is no way of knowing how much credit is "enough," it is not clear that a credit infusion of this magnitude could be successfully absorbed.

One cannot, then, attribute the inverse relationship between size and relative scalc of minority lending solely to tokenism on the part of banks. To an important extent, this relationship merely describes the existence of the problem to which minority entreprencurship efforts address themselves that non-whites are under-represented in the busincss class, and that the opportunities for minority group persons to begin businesses are inadequate.

45. See p. 624 supra. 
perience as well, banks must relax traditional credit criteria-such as insistence on collateral, a personal investment by the entrepreneur, large compensating balances, and a high level of management expertise-if they are to make a substantial volume of minority loans.

Because the banks had not formulated precise credit criteria to be applied in their minority lending programs, the field interviews attempted to explore the attitudes of bankers toward traditional credit prerequisites.

While many of the lending officers felt that they had become more cautious since the beginning of their minority lending programs-that they had become increasingly concerned about avoiding failures-all expressed some willingness to forego traditional ground rules. Ten banks, for example, reported that they had on occasion loaned money to minority borrowers in the absence of equity, although they emphasized that the loans were made only after an unsuccessful search for outside equity. Thirteen banks reported that they undertake efforts to locate equity financing for borrowers when they are anxious to make a loan but for this deficiency. In most cases, there is no institutional equity source, and investment funds are obtained, if at all, from private individuals. The SBA's waivable requirement is that equity financing equal at least $15 \%$ of the total financing, ${ }^{40}$ and most banks accept this as a reasonable guideline. This compares with the more traditional rule of thumb that equity must amount to $50 \%$ or more of the total financing, and two banks felt that the SBA's $15 \%$ standard was too low.

Some bankers manifested a concern with the source of equity as well as its quantity. ${ }^{47}$ Their insistence that equity financing be provided by

\footnotetext{
46. I Farr 130, 134.

47. The Nixon Administration has begun a program designed to produce a supply of "outside" equity financing. The program is an adaptation of the Small Business Investment Company (SBIC) to the needs of financing minority-owned businesses. The new vehicle is simply an SBIC devoted to minority lending, with apital and orerherd expenses provided by a parent corporation. It is called a Minority Enterprise Small Business Investment Company (MESBIC). Unique to this approach is its ability to leverage privite capital paid into the MESBIC. Capitalization at X enables the AIESBIC to sell debentures to the SBA in an amount equal to $2 \mathrm{X}$. Total capital is then three times the original capital. The minimum initial capitalization of $\$ 150,000$, then, results in $\$ 450,000$ for equity investment. Office of Minority Business Enterprise, U.S. Depurtment of Commerce, Project Enterprise Information Kit (undated) [hereinafter cited as OMBE, Information Kit].

Incentives for private capital to invest in MESBIC's are, however, slim. SBIC's and their investors are allowed an ordinary-loss deduction rather than a capital-loss deduction for investment losses and losses on sale of SBIC stock. INr. REv. CoDE of 1954, $\$ \$ 1243$, 1242. SBIC's may also be allowed a $100 \%$ deduction for dividends received on investments in domestic corporations. INT. REv. ConE of 1954, $\$ 243(a)(2)$. There are no incentives for MESBIC's above those available for regular SBIC's.

The response to the MESBIC program has been poor. Only nine MESBICs had been chartered as of June 28, 1970-the target goal of 100 was to have been reached by
} 
the borrower himself, if applied rigorously, would preclude significant expansion of lending to high-risk minority borrowers.

Bankers took a variety of positions on other credit criteria. Three banks have begun to reverse their early policy of lending money to minority applicants on the basis of job skill alone, and have begun to insist on management experience as well. Seven emphasized that they now avoid small loans to retail trade and service businesses because in their experience these were the most demanding and the most likely to fail. Five banks insist on tightly structuring a loan, taking liens on whichever of the borrower's assets they can in the interest of tying the borrower to the success of his business. Only one of these five disapproved of taking liens on personal property.

In general, the bankers believed that the "proper" policy is not simply to waive credit prerequisites, but to plan as carefully as possible to maximize the chances of success for those businesses that are to receive credit.

\section{The Availability of Liberal Repayment Terms}

From the perspective of the high-risk borrower whose business may be financed almost entirely through debt, liberal loan repayment terms are essential if he is to manage his business while meeting his repayment obligations. Typically, the borrower desires such repayment features as an interest-only grace period at the outset, a manageable interest rate, and a long maturity.

Banks were generally willing to provide liberal repayment terms to accomodate the businessman's cash-flow capabilities. All claimed that minority borrowers get more flexible repayment terms than regular small business customers. In particular, eleven specified that interestonly grace periods were common, although only four reported that such periods lasted for one year or more on most loans. ${ }^{48}$ Eight of the banks reported that the average maturity of their loans is 5.7 years,

June 30. As Under Secretary of Commerce Siciliano said on June 28, "It's hard to imbue businessmen with social consciousness when business is bad." N.Y. Times, June 29, 1970, at 1, col. 6. The MESBIC program was given a substantial boost on December 1, 1970, when the Ford Foundation announced grants and loans totalling $\$ 2.5$ million to six MESBICs involving black, Puerto Rican and Indian communitics. Ford Foundation Press Release, December 1, 1970. Secretary of Commerce Maurice Stans admitted the program's lack of success when he commented that the Foundation's contribution gave MESBIC " $\mathrm{a}$ dignity and status that has been difficult to achieve," and that the Ford support liad provided "more stimulus than MESBIC has had since it was established." N.Y. Timeg, December 2, 1970, at 71, col. 1 .

48. Yet the EOL guarantee program allows such periods for up to 18 monthy. 18 C.F.R. \& 119.31(b) (1970). 
and only two adhered to the more traditional 3-5 year limit for small business loans.

Interest rates charged to minority borrowers under the special programs varied substantially, from $7.5 \%$ to $12 \%$ simple interest, with six banks making most of their minority loans at 1.5 points above the prime bank rate. Two banks charged the same rates as for regular small business borrowers, and another two consciously charged more, in recognition of the increased risk and cost of making minority loans.

In the case of high-risk minority borrowers, then, relatively low rates are being extended despite high risk, small compensating balances, and relatively large administrative costs. Although only one of the banks interviewed claimed to have tested empirically the net cost of its minority lending program, all report that these programs are, on balance, costly. ${ }^{49}$ As noted, from the banks' perspective, the loans are "soft."

\section{Institutionalization of Minority Lending: Administrative Arrange- ments.}

Broadly speaking, institutional arrangements employed by banks for the operation of minority lending programs are of two types, those conducted by banks themselves ("in-house"), and those conducted by separate agencies sponsored by banks ("external"). Both types have variants, each with peculiar advantages and disadvantages.

\section{In-House Programs}

Findings. Thirteen of the banks studied had in-house programs. The primary issue faced by a bank setting up an in-house program is whether the program should be centralized or decentralized, although only banks in states which allow branch banking are seriously confronted with this choice. Banks in Chicago and Denver, for example, are confined by state law to one banking location only ("unit banking"). In New York, Pennsylvania, Georgia, ${ }^{50}$ and California, banks are permitted one form or other of branch banking. Only three of the eight banks

49. Interview with E. Bowman McLean, Colorado National Bank, in Denver, July 21 , 1970 [hereinafter cited as McLean, Colorado National Interview]. Mir. MIcLean estimates that it costs his bank $\$ 1,000$ net of income generated to make and service a $\$ 20,000$ minority enterprise loan. Most other banks interviewed showed surprisingly litule interest in knowing the net cost of their programs. This suggests that minority lending efforts are not thought of as being regular bank business. See pp. 641-42 infra.

50. Branch banking was allowed in Georgia at the time the Citizens \& Southern National Bank was expanding. Interview with William W. Mfalone, Citizens and Southern National Bank, in Atlanta, July 14, 1970 [hereinafter cited as Mialone, C \& S Interview]. 
which had a branch banking system chose to maintain a central site for their minority lending programs.

Implications. The bankers interviewed felt that the relative merits of the centralized and the branch banking programs should be analyzed in terms of outreach to minority borrowers, stigma attached to borrowers, and incentives to lending officers to make high-risk loans.

The great disadvantage of a centralized system, unless conducted in a neighborhood readily accessible to potential borrowers, is greater difficulty in attracting customers. To cope with this problem, a bank must place more emphasis on outside referral sources. Another disadvantage perceived by the bankers is that banks which have branches but conduct minority lending at only one office open themselves to charges of tokenism and racism in that a high-risk minority borrower must go to a particular place and is unwelcome at other branches.

On the other hand, centralized programs have one fundamental advantage-the lending officers who process the applications are typically part of a special minority enterprise unit which is not expected to generate profit. The officers quickly develop at least some expertise in the problems of minority borrowers and are thus likely to be both more sympathetic and more effective than ordinary lending officers.

The programs which utilize branch banks are likely to have fewer problems with outreach and stigmatization. Their great disadvantage is lack of control over the conduct of lending officers. A strong disincentive exists for the typical lending officer to become involved with a minority borrower. Even if a bank's management has announced a commitment to minority lending, the lending officer is faced with the reality of periodic evaluations for salary increases and promotions. Minority enterprise loans tend to be more time-consuming than others (estimates vary from twice to ten times as much time required), they are smaller, and they generate relatively insubstantial deposits. Furthermore, such loans are more likely to be delinquent, thereby requiring even more time, and they are more likely to fail. For a credit officer who is evaluated on the basis of how much income is generated by his total time expenditure, the incentive to avoid minority enterprise lending activity is plain.11

Three banks have identified and made attempts to cope with these disincentives. The Chase Manhattan Bank has established a Community Economic Development (CED) division, which oversees the

51. Interview with John E. Williams III, First Pennsylvania Banking \& Trust Co., in Philadelphia, July 6, 1970. 
minority lending efforts of branch officers and acts as an internal risk guarantor. The GED lends no money itself, but participates in the processing of minority enterprise loans. Most notably, the program has implemented a first step toward reducing the disincentive to lending officers by coding minority enterprise loans into the computer by branch and lending officer and also by CED code number. The branch and lending officer get credit for all income generated, but the GED is charged if the loan is defaulted.52 A second bank, Wells Fargo in California, has implemented the same type of internal risk guarantee. ${ }^{53}$

At neither of these banks, however, is the disincentive completely met. The sheer time-ineffectiveness of minority lending remains, notwithstanding removal of risk. A third bank, the Bank of America in California, has attempted to meet this problem by allowing $20 \%$ "extra" or unaccounted-for time to its low income neighborhood branches. ${ }^{54}$ Alternatively, the disincentive could be counteracted by adding some "shadow" amount onto the profits actually generated by the particular officer.

The principal general advantage of an in-house arrangement is its relative normalcy-borrowers are not stigmatized (or at least may not be), and bankers have the opportunity to deal directly with a type of borrower new to their experience. Ultimately, such contact may help to reduce racial discrimination in the credit market. A concomitant disadvantage, however, is that bank public relations departments may descend on a program, introducing new and dysfunctional administrntive concerns. ${ }^{55}$

\section{Externalized Programs}

Findings. In four of the cities in which interviews were conducted, banks had established, either independently or in concert, external vehicles, each on a different model.

(a) The Single Bank External Lender. The Citizens \& Southern Bank merely created a separate organization, called the Citizens \& Southern Development Corporation, to engage in minority lending. The parent bank provided $\$ 2$ million from its loan loss reserves for hous-

52. Toal, Chase Manhattan Interview.

53. Interview with Thomas TW. Stoddard, Wells Fargo Bank, in San Francisco, July 24, 1970.

54. Angello, B of A Interview.

55. Toal, Chase Manhattan Interview. 
ing loans and loans to minority entrepreneurs, ${ }^{66}$ and pays the new vehicle's annual operating expenses.

(b) Multi-Bank Risk Sharing. Philadelphia's Job Loan Corporation (JLC) is a consortium of eight banks which agreed to lend money to minority entrepreneurs through JLC until total chargeoffs reached $\$ 2$ million. Anticipated chargeoffs were $25 \%$ of dollar volume, making the total projected loan availability $\$ 8$ million. JLC does not make loans directly, but instead authorizes its guarantee of loans which are actually made by member banks. When a loan authorized by JLC and made by one of the member banks fails, JLC sells notes to the member banks. Each bank buys a note bearing the same proportion to the total loss as that bank's size bears to the aggregate size of the member banks; the losing bank is then repaid. ${ }^{57}$ JLG's staff also does rudimentary "packaging," but is not substantially involved in post-loan assistance. . $^{59}$

(c) Multi-Bank Risk Sharing and Lending. A group of San Francisco banks in February 1969 initiated an organization named Opportunity Through Ownership (OPTO), incorporated under the California Job Development Corporation Law..$^{50}$ The consortium of banks lends OPTO money and shares its losses, allocating them to member banks proportionately to their sizes. ${ }^{60}$ Distinguishing characteristics of OPTO are that it loans money directly to borrowers and that it seeks out largescale minority business ventures which promise considerable growth and which are unbankable mostly because they are short of equity financing. Because it is chartered as a Job Development Corporation under California law, ${ }^{\text {11 }}$ OPTO is qualified to receive state loan guarnntees, which are flexible but scarce. ${ }^{62}$ Thus far, $\$ 200,000$ of the $\$ 1.7 \mathrm{mil}$ * lion committed by OPTO has been so guaranteed. ${ }^{.3}$

(d) Multi-Bank External Processor. The Colorado Economic Development Association (CEDA) is a pure packaging agency funded by participating banks, the SBA, and a local foundation. It conducts courses and seminars on business topics for minority borrowers, prepares loan applications and accompanying documents, and conducts a 6-month follow-up program to provide rudimentary post-loan assis-

56. Malone, $\mathrm{C} \& \mathrm{~S}$ Interview.

57. Zucker, JLC Interview.

58. Interview with Ronald Pappas, Girard Bank, in Philadelphia, July 8, 1970; Zuckcr, JLC Interview.

59. Job Development Corporation Law, Cal. Corp. Code \& 14,000 et seq. (West).

60. Id. \& 14073 .

61. See note 59 stspra.

62. Cal. Corp. Code \$\$ 14040-14046 (West).

63. Interview with Melvin C. Yocum, Opportunity Through Owncrship, in San Fran. cisco, July 23, 1970 [hereinafter cited as Xocum, OPTO Interview]. 
tance. ${ }^{84}$ Completed loan applications are sent to one of the four participating banks, where some $80 \%$ are approved.05

Implications. Freedom from control and public relations manipulation, greater professionalism, and economies of scale are potential advantages of external organizations. An external agency may be better able to maintain credibility in minority communities than is a large bank, and may as a result have superior outreach, a community planning aspect and greater ability to select promising entrepreneurs from among loan applicants.

Depending on the nature of the relationship between sponsor banks and the resultant external programs, however, externalization may permit a bank to flee the problems of minority entrepreneurship relatively cheaply, thus contributing little to the institutionalization of minority lending. This general problem of an external vehicle enabling a bank to avoid the challenge of financing minority enterprises is exacerbated when that vehicle lends money directly, because direct contact of the banks with minority borrowers is reduced."0

Additional incentives to such behavior come in the form of mutual risk guarantees, which also serve to make lending through the external organization relatively more attractive than the development of inhouse lending capabilities to match the need of high-risk minority borrowers. ${ }^{67}$

The external processor model has the potential for realizing important economies while aiding the institutionalization of minority lending. If the external processor performs those processes which banks are not wellequipped to execute, ${ }^{68}$ such as packaging and post-loan assistance, it can spread the cost of developing such a capability among member banks, and perhaps realize scale economies as well. Important to the

64. Lucero, CEDA Interview; Colorado Economic Development Association, Annual Report, August 1970 (unpublished mimeo).

65. Lucero, CEDA Interview.

66. Only two of the San Francisco clearinghouse banks have undertalien independent minority enterprise lending programs. Yocum, OPTO Interview.

67. Only three of the eight banks which formed the Job Loan Corporation in Philadelphia have independent minority enterprise lending programs. Zucker, JLC Interview.

68. Every banker who did not avoid the question agreed to some extent with the proposition that the main reason, apart from racism, why minority group businessmen hnve not received much credit is that bankers have never been in the business of making very sophisticated judgments among various credit risks, but have instead lent money under heavily "protected" circumstances, typically resting on solid collateral and large deposits. By offering none of these protections, the potential black entrepreneur's loan application forces the banker to analyze risk with greater care. And this is a task for which many lending officers have not been adequately prepared. A fortiori, bankers are now langely unable to perform expert packaging and post-loan assistance, and it is unlikely that they will develop this capability for the sake of dealing with unprofitable minority group customers. 
institutionalization of minority lending, however, is the continued involvement of bank personnel in the lending process. CEDA has maintained such involvement by insisting that bank personnel participate in the final stages of packaging, and in post-loan review and assistance for the first 6 months after the loan. ${ }^{69}$

\section{Conclusions}

Subject to the qualifications expressed throughout the Note, ${ }^{70}$ available evidence suggests that the flow of loans from commercial banks to high-risk minority entrepreneurs has substantially increased as a result of government incentives, government prodding, a declared industrywide policy, and various "soft" incentives generated within major" banks. The rate of increase, however, was greatest during fiscal 1969, and levelled off in important respects during fiscal 1970. The SBA's goal of 10,000 businesses in fiscal 1969 and 20,000 in fiscal 1970 was not reached. The ABA's goal of $\$ 1$ billion in minority loans by 1975 would require an average of $\$ 142.9$ million per year, and this has not been reached either.

The evidence gathered suggests that a large proportion of minority loans have been made to businesses of relatively small size, engaged in retail and service fields. These businesses have the highest chance of failure and represent relatively small income and employment potential for the entrepreneurs and for minority communities in general. ${ }^{71}$

The field survey shows that in the most "active" banks, loans are being made to borrowers with little management and skill experience, no collateral, and little or no personal savings to invest. Some bankers find that financing businesses which have no equity base is simply too risky, and are reacting to high early failure rates by tightening credit prerequisites somewhat.

Although the continued unprofitability of minority lending and the relatively liberal credit terms available for minority borrowers at "active" banks suggest that minority lending by these banks consists primarily of "soft" loans, this "softness" is, in turn, a principal obstacle to the institutionalization of minority lending. For while liberal loan terms are essential for borrowers who lack equity financing, the unprofitability of high-risk minority lending undermines the prospect of such lending being conducted by banks as a matter of course.

69. Iucero, CEDA Interview.

70. See notes $14,17,23,37,41$, and pp. 620-21 supra.

71. See note 40 supra. 
It is clear that some banks which do not have independent programs are making SBA-guaranteed loans. It may be that these loans are unprofitable, and are made in response to government prodding. But it may also be that the loans are profitable, either because these banks have loaned money to borrowers in a risk range where the SBA guarantees have effectively "hardened" the loans, or because the banks are "creaming" by obtaining SBA guarantees on loans which are not genuinely high-risk. ${ }^{22}$

The field survey banks, all of which had established independent high-risk minority lending programs, used relatively few guarantees, and their programs were in most cases unprofitable. This unprofitability is underscored by the fact that only eighty-nine of the nation's three hundred largest commercial banks had established such programs. ${ }^{33}$ Why, then, have special minority lending programs been undertaken? Three reasons were given by the bankers interviewed. By far the most common is "corporate goodwill," or "business obligation" or a similar variant on the theme of public relations. Theodore Cross suggests this motive is rather less "soft" or altruistic than it might appear-by undertaking voluntary compliance, banks help to guard against a possible statutory mandate to make a fixed portion of their loans in ghetto areas. $^{.74}$

A second reason is that some banks hope that their minority enterprise loan programs will attract young job applicants concerned with social involvement.

A third reason frequently given by bankers is that minority enterprise programs are in some vague way consistent with long-run profit maximization. Urban banks are faced with home markets increasingly populated by non-whites. Bankers reason that by making an effort to foster minority businesses, they help to create new customers and learn to deal with the market on which they increasingly depend. Given the national and international scope of dealings by major banks, however, this rationale is tenuous.

A fourth reason, given by Cross but by none of the bankers interviewed, is the persuasion of the federal government. ${ }^{75}$ An excellent example is Howard Samuels' extensive travel and exhortations in behalf of Project OWN. The fact that this kind of persuasion, plus the spectre of urban rioting, was necessary to induce banks to expand minority

72. See note 37 supra.

73. ABA Survey, at 9 .

74. T. CRoss, BLAcK CaptralisM 128 (1969).

75. Id. 124-26. 
lending only serves to underscore the observation that high-risk minority lending programs are not currently predicated on quantifiable profit maximization. ${ }^{6}$

This is not to disparage the far-sightedness of certain banks' management, as shown by their commitment of resources to minority lending. It is, rather, to observe that bankers like other businessmen are concerned with profits. Incentives which do not affect the objective cost-benefit calculus are inherently uncertain.

As for the other aspects of institutionalization, those relating to the administration of minority lending programs, no clear pattern emerges. The problems of outreach to potential borrowers, stigma, and lending officer incentives have not been solved in most banks. Some banks have successfully avoided one or more of these difficulties, but no single bank program stands out as a complete success.

Several policy recommendations to improve bank performance with respect to financing free-standing minority-owned businesses are suggested by the analysis above. Some progress has been made in providing debt financing to high-risk minority borrowers. Yet consistent progress toward the five sub-goals of minority lending cannot be expected until such lending is made profitable.

The SBA loan guarantee programs should be changed in certain respects. The guarantee ceilings on all SBA loans should be increased to $100 \%$. Risk is only one aspect of the disincentive to minority lending, but there seems no reason why it should remain. The current disparity between guarantees available in the EOL and 7(a) programs merely serves as an incentive to small loans, which is precisely the wrong way for incentives to point. ${ }^{77}$

Some banks are now deterred from seeking SBA guarantees when the appropriate loan form is a line of credit to meet seasonal and inventory needs, since the SBA will guarantee only loans with fixed amortization schedules. ${ }^{78}$ SBA guarantees should be expanded to include such lines of credit.

76. Further supporting evidence is found in the history of the sample banks' involve. ment. Only one bank in the sample had undertaken a special program before the 1967 riots. Eleven began their programs after the assassination of Reverend Martin Luther King, Jr., and only five of those began after the initiation of Project OWN. A tentative suggestion from this pattern is that the motivation informing a bank's decision to start a special program to lend money to high-risk borrowers is less a response to the reduced risk offered by Project OWN than to other factors.

77. See note 40 supra. The $90 \%$ maximum guarantee on 7(a) loans is not mandated by statute. See 15 U.S.C. $\$ 636$ (Supp. V, 1970). It has been an administrative featurc of the program, however, since 1954. See 19 Fed. Reg. 5541 (1954) at $\$ 101.4$ (c)(2). Foward Samuels, without explanation, simply reitexated this policy. 33 Fed. Reg. 18276 (1968). The $90 \%$ maximum appears at 13 C.F.R. \& 120.2(b)(2) (1970).

78. Toal, Chase Manhattan Interview. 
More expeditious SBA approval procedures would reduce the cost to banks of obtaining loan guarantees. The Chicago SBA office has recently introduced an automatic blanket guarantee plan which allows for an automatic guarantee if a loan is not rejected by the SBA within three days of receipt of the application. ${ }^{70}$ A slightly better system which might be implemented nationally would be similar to that now used for Federal Housing Administration mortgage guarantees. A bank under this system would be authorized to commit the government guarantee on its own discretion, and would be subject only to a post-loan audit.

Further incentives, however, will be necessary if banks are to overcome the inordinate unprofitability of minority lending. Such incentives could take a number of obvious theoretical forms. ${ }^{80}$ Apart from SBA and California loan guarantees, however, only one incentive model was discovered in operation during the field research. This was found at the Hyde Park Bank \& Trust Company in Chicago, the only bank interviewed which operates its minority enterprise program at a profit. ${ }^{81}$ This model, based on a variation of the State of Illinois' linked deposit program, ${ }^{82}$ is designed to use the earnings on state deposits to pay for the administrative expenses of a full-time minority lending staff. The State Treasurer provided time deposits of $\$ 2.5$ million and demand deposits of $\$ 1.0$ million as part of this experiment. ${ }^{83}$

When the interview was conducted, the Hyde Park bank still had $\$ 2.5$ million in state deposits. It had expanded on the program, however, by soliciting corporate deposits of $\$ 3$ million made specifically

79. Interview with Russel H. Ewert, First National Bank of Chimgo, in Chiago, July $9,1970$.

80. Possible incentive models might be: repeal of the usury laws, thereby allowing banks to charge minority borrowers interest rates commensurate with risk and administrative costs, with direct grants being made to borrowers to make debt service costs tolerable; banks could be subsidized directly, according to the amount loaned to minority borrowers; or banks could be given tax incentives to undertake minority lending. Any comparative evaluation of these incentive models would be highly speculative, as none has been implemented. Such evaluation is beyond the scope of this Note.

81. Davis, Hyde Park Interview.

82. State Treasurer Adlai $\mathrm{E}$. Stevenson III initiated the linked deposit program shortly after taking office in 1967. The program's objectives were to allocate public funds so as to maximize earnings and reduce the need for tax revenues, to equalize regional distribution of state funds, and to use public funds to permit and stimulate private investment to serve public needs. The program was implemented starting February 1, 1963, and allocated $\$ 240$ million in idle state funds under a Basic and Supplemental Deposit Program. Thirty-five per cent of those funds went for Supplemental Deposits, directed to banks on the basis of their lending in specified areas, including "Community Service." The Hyde Park experiment was an adjunct to this linked deposit effort. Systemetrics, The Impact of Linked Deposit Programs For Allocating Public Funds II-B-7-II-B-19 (unpublished manuscript prepared for the Ford Foundation, 1968).

83. Id. at II-B-19. 
in support of the bank's minority enterprise program. These deposits do not constitute a loan pool for minority enterprises. Instead the bank allocates a portion of the earnings on the Urban Development Division Sponsors' accounts to pay the expenses of that division. The Division director reports that this combination of private and state deposits, linked to a specified form of activity, has enabled the Division to function at a profit. ${ }^{84}$

Of course the incentives constructed in the Hyde Park model are not uniformly hard. Corporate accounts garnered receive competitive interest returns but doubtless cost the corporations somewhat more to administer when located at an extra bank with which they do not normally do business. Yet the extent to which this bank program rests on non-pecuniary incentives is negligible compared to all other bank programs.

The Hyde Park model represents an important demonstration of the potential efficacy of the linked deposit concept as an incentive to bank lending to minority entrepreneurs. Hyde Park's minority loans equal $7.5 \%$ of its outstanding total loans, which is by far the largest proportion of minority loans found at any of the banks interviewed.

The linked deposit concept might be adopted by state and federal governments as one way of compensating private lenders for lending money for specified, socially "important" uses. It is difficult to estimate the consequences in terms of minority enterprise and other public efforts of channeling public funds (and perhaps corporate funds, which might be a demand of "public interest" shareholder groups) in this way. But the orders of magnitude of deposited public funds are large. In fiscal 1967, for example, $\$ 24$ billion was held by state governments in cash and securities, apart from the funds held under provisions of various state insurance and pension trust systems. ${ }^{85}$ These essentially idle funds are normally allocated in the discretion of state treasurers..$^{80}$

The analysis above has been predicated on an existing state of affairs as to other stages of the business creation process. But recommencla-

84. Davis, Hyde Park Interview.

85. Systemetrics, note 82 supra, at II-1. No similar compilation is readily avalable for all federal government funds, as bank deposits are reported on an agency basis. Presumably, however, the amounts are quite large.

86. Id. at II-4. In some states, however, treasurers are prohibited from investing idle cash balances in either time deposits or securities.

Even larger amounts are held by states under various trust fund and insurance fund arrangements. In fiscal 1967 , this totalled $\$ 40$ billion for all states. Typically, there are more restrictions on allocation of these funds, but the Systemetrics report concludes that "state trust-system funds represent a very significant potential source of long-term funcls to finance federally-assisted public facilities and housing programs." Id. at II-5. 
tions of programs to improve the minority lending performance of commercial banks need not be limited to the debt financing stage alone.

"Packaging" services are available in some cities from organizations established by the federal government, corporations, foundations, and, in some instances, banks. ${ }^{87}$ The existing packagers are, however, to few and typically understaffed. The size and number of these agencies should be expanded.

Post-loan assistance is not currently available in most cities, yet, in the opinion of every banker interviewed, is important if businesses financed under minority lending programs are to succeed. The only important model for the provision of post-loan assistance is the Arcata Management Company in Menlo Park, California, funded by an SBA technical assistance grant in March 1970.88 The Arcata model is designed to provide free management and technical assistance for the forty-six customers of the Arcata Minority Enterprise Small Business Investment Company ${ }^{89}$ and for eleven other minority-owned enterprises. Assistance is provided by the Management Company's full-time staff and by professional consultants whose services are hired as needed. Some of these consultants volunteer their services..$^{00}$

Such capabilities should be incorporated into packaging agencies. Minority borrowers could thus get pre- and post-loan supportive services from the same source. Packagers could charge some monthly fee to borrowers using the service, though the high cost of such services would probably necessitate government funding as well. ${ }^{01}$ Under this arrangement, packagers would employ full-time management consultants and might retain, perhaps at a reduced rate, lawyers, accountants and bookkeepers whose services would be available to borrowers as needed. ${ }^{92}$

Equity financing is another stage of the process of minority business formation where outside aid is largely unavailable..$^{33} \mathrm{~A}$ public program

87. See note 8 supra.

88. Interview with Robert J. Evers, Arcata Management, in Menlo Park, Californis. July $23,1970$.

89. Id.

90. Id.

91. The Arcata Management Company's 1-year grant, for example, is for $\$ 143,750$.

92. Interview with Benjamin Goldstein, National Council for Equal Business Opportunity, in Washington, D.C. July 1, 1970. The concept of a management company is also supported by Lawrence Toal, Chase Manhattan Bank.

93. Apart from the few MESBICs, some packaging agencics have small amounts of equity financing, e.g. the Rochester Business Opportunities Corporation and Coalition Venture Corporation in New York City. The Chicago Economic Devclopment Corporation is one of the recipients of a Ford Foundation investment to start a MIESBIC. 
might be created to tap the existing large pools of investment funds now managed by banks as trustees. ${ }^{04}$ Such a policy would have to involve complete risk guarantees as well as incentives in the form of a guaranteed level of earnings on the entrusted accounts. ${ }^{\text {.t }}$

If expanding minority entrepreneurship is to remain an aspect of national policy aimed at bringing about racial equality, and if the encouragement of free-standing minority-owned businesses is to continue as part of that policy, changes of the sort recommended above will have to be implemented. The common theme which runs through the recommendations is a greater commitment of economic resources. With the conspicuous exception of loan guarantees under Project OWN, federal efforts have tended to rely on exhortations. Private efforts, as a consequence, have tended to be motivated by good will and public relations. It is doubtful whether any public policy can be sustained by such slender reeds.

94. A clear obstacle to such uses of trust accounts is the doctrine of fiduciary responsl a bility. The standard of care for trustees is that trust investments must be such as a reasonably prudent man would make of his own property under the circumstancey, having primarily in mind the safety and productivity of the investment. Harvard College v. Amory, 26 Mass. (9 Pick.) 446, 461 (1830). See also RESTATEMENT (SECOND) or TRusis § 227(a).

95. A complete risk guarantee would presumably meet the requirement of safety. Un. secured loans in many states have been deemed improper uses of trust funds, but unsecured time deposits in banks are no longer imprudent because they are insured by the Federal Deposit Insurance Corporation. III ScoTr ON TRusTs $\$ 227.8$ (3d ed. 1967). The productivity requirement would have to be met by a guaranteed level of carnings, perhaps equal to the average earnings of the trust account. The conservatism of trustecs would likely remain an obstacle, and an added yield guarantee would have to be includecl. Without experimentation, it must remain unclear how large that incentive would have to be, and how much such a program would cost. 